\title{
The Contribution of Thaler to Behavioural Economics*
}

\author{
Gábor Neszveda
}

Richard Thaler was awarded the Nobel Memorial Prize in Economic Sciences in 2017 for his contribution to behavioural economics. The main purpose of behavioural economics is to build a bridge between economic thinking and the results of psychological research. Below, I present the fields where the work of Thaler stands out the most, such as limited rationality, lack of self-control and social preference. In addition, his findings also laid the foundations for behavioural finance. His unwavering, successful and high-standard research over more than forty years has laid the foundations for a number of new research directions, not only in sciences. The elaboration of the theory of libertarian paternalism, among others, is also associated with his name, which has substantially shaped many decision-makers and regulations over the past decade.

Journal of Economic Literature (JEL) codes: D03, D90, G02, G40

Keywords: behavioural economics, behavioural finance, limited rationality, social preference, lack of self-control, Nobel Memorial Prize

\section{Introduction}

Richard Thaler was awarded the Nobel Memorial Prize in Economic Sciences in 2017 for his contributions to behavioural economics. Behavioural economics builds a bridge between psychological and economic approaches. Psychological research tends to apply descriptive approaches and observes how people take decisions. Then it categorises the observations, but often fails to develop a formal normative model. By contrast, economic models prefer to apply a normative approach and try to describe how economic systems and decision-makers should operate under a given set of assumptions. This train of thought leads to the creation of the homo oeconomicus. Homo oeconomicus behaves in line with the assumptions of the economic models, but completely ignores human characteristics. As opposed to this, Thaler proposes placing the observation of human behaviour into the focus of * The views expressed in this paper are those of the author(s) and do not necessarily reflect the offical view
of the Magyar Nemzeti Bank.

Gábor Neszveda is an assistant lecturer at the MNB Department of Corvinus University of Budapest. E-mail: gabor.neszveda@uni-corvinus.hu

The Hungarian manuscript was received on 15 December 2017.

DOI: http://doi.org/10.25201/FER.17.1.153167 
economics, instead of analysing the homo oeconomicus. In his research work, Thaler has incorporated psychological theories into economic questions, and promoted the use in economics too of approaches accepted in psychological research. As a result, experiments became more accepted in economics, and economic models started to incorporate human behaviours observed in psychological research.

Behavioural economics is a fairly new but increasingly popular field of economic sciences. A clear sign of this is that 15 years ago, in 2002, Daniel Kahneman and Vernon L. Smith were also awarded the Nobel Memorial Prize in recognition of their contribution to behavioural economics and experimental economics. Their names and scientific achievements are often linked to the emergence of behavioural economics. Thaler and Kahneman have co-authored a number of studies and their research topics are closely related. The research work of Kahneman has mainly been recognised for its results achieved in the field of risk preferences, while the work of Thaler is mostly known for the findings in the field of time preferences. But the common denominator of the two scientific lifetime achievements is that they both argue for reviewing the assumptions of economic models. They refuse to accept the assumption that decision-makers always follow their own interests and that they always consciously take the decision which is best for them. In their view, decision-makers take into account not only their own selfish interests but also the interests of the community. Besides, humans frequently tend to resort to simplifications, which rarely leads to the best decision. These principles appear on financial markets and in investor psychology too. Thaler is also considered the founder of behavioural finance for his research conducted in this field. Using the summary of the Royal Swedish Academy of Sciences (2017) as well, in this paper I present the three main areas of Thaler's work as well as the impact of his research results on decision-makers and financial thinking. First, I review the theory of limited rationality, and as part of this, the endowment effect and the theory of mental accounting. Then, I present research studying the lack of self-control, and thirdly, his research conducted in the field of social preference. Finally, I give a short overview of the impact of his results on various public issues. My study does not extend to a detailed analysis of the mathematical models.

\section{Limited rationality}

Mainstream economics assumes the complete rationality of decision-makers. Although this assumption entails a number of mathematical advantages in the model, it is not supported empirically. Behavioural economics assumes that in the case of more complex and complicated issues, people use simplifications, or heuristics and take their decisions based on these ${ }^{1}$. One of the most frequent

\footnotetext{
${ }^{1}$ Golovics (2015) gives a detailed overview of the topic.
} 
reasons behind simplification is the insufficient level of cognitive capacities. A number of economic models assume that decision-makers reach their ultimate decision by resolving serious optimisation problems, but in contrast, it is difficult to believe that an average person optimises in reality prior to taking a decision.

\subsection{Endowment effect}

The endowment effect is the hypothesis that people ascribe more value to things merely because they own them. One of the most famous examples of the endowment effect was when the participants to the experiment were randomly given a cup or a pen that they could trade (Kahneman et al. 1990). What they observed was that participants asked twice as much for items they owned than what they would have been willing to pay for when they wanted to buy. This means that the participants of the experiment overvalued the cup or the pen once they owned it, but undervalued those they did not yet own. Thaler had already examined this phenomenon in his doctoral thesis (Thaler 1980), but still in the form of hypothetical questionnaires.

According to the neoclassic approach, nothing can have two different values at the same time, depending on the method of questioning. By contrast, the example also supports the fact that the value we are willing to pay for something is a lot lower than the value at which we are willing to give it away. This is what we call the endowment effect.

Thaler explains the phenomenon in that people tend to be loss-averse. If we own something, then giving it up is already a loss, so it is a lot more painful than if we only wanted to obtain it. This has been examined again and again in a large number of experiments. Tuncel and Hammitt (2014) reviewed 76 published experiments containing 337 estimations of how much more people would ask for something than what they would be willing to pay for it. The difference was huge, more than threefold on average. The correlation is clear, this difference diminishes if the product has a well-known financial value, and increases with the difficulty in evaluating the product.

\subsection{Mental accounting}

One of the motivations of mental accounting is the empirical observation that people tend to group their expenses according to various categories, such as food, housing expenses, entertainment, etc. By assuming that people tend to have a number of individual accounts for the various categories with a separate budget, and converting between the different accounts is limited, the theory of mental accounting wants to capture this very feature. As a result, a given decision depends on how it is formulated and to which account it belongs. 
For example, they found that taxi drivers in New York (Camerer et al. 1997) have a revenue target that they wish to attain for each day. According to the theory, each day is a separate account where revenues are kept, and every account is managed and optimised separately. As a result, taxi drivers will stop working sooner on days when they can obtain more money for a trip, since they can achieve their daily target faster due to the higher price. But this observation completely contradicts general economic thinking. Higher revenues should encourage them to work more to offset the more difficult days in the future.

A famous experiment of Tversky and Kahneman (1981) also supports the fact that people usually don't examine the joint effect, but instead, they narrowly interpret the effect of the decision. In this experiment, participants had two decisionmaking situations and the combination of the consequences of the two decisions determined the ultimate payment in the example.

In the first decision-making situation they were able to choose from the following two options:

a) A certain profit of $\$ 240$

b) A 25 per cent chance of gaining $\$ 1,000$, or a 75 per cent chance of gaining nothing In the second decision-making situation, the participants could choose from the following two options:

c) Certainly lose $\$ 750$

d) A 75 per cent chance of losing $\$ 1,000$, or a 25 per cent chance of losing nothing

In the experiment, 73 per cent of the participants opted for (a) in the first case and (b) in the second case. But this decision is necessarily worse than if they had opted for options (b) and (c), because the combined effect of decisions (a) and (d) is that they have a 75 per cent chance of losing $\$ 750$, or a 25 per cent chance of winning $\$ 240$. By contrast, deciding for options (b) and (c) means that they have a 75 per cent chance of losing $\$ 750$ and a 25 per cent chance of gaining $\$ 250$. So, the outcome of choosing options (b) and (c) always offers a better payment than choosing options (a) and (d), still, the majority opted for options (a) and (d). It is difficult to interpret if the participants really took their decisions based on the combined effect, but it can be easily explained in so far as they evaluated the two decisions individually, because it is a known fact that people are risk-averse in the case of gain, and risk lovers in the case of loss (Tversky-Kahneman 1979).

The theory of mental accounting also had a tremendous impact on the analysis of financial markets since it questions one of the most fundamental assumptions of financial modelling. Financial modelling assumes that investors optimise the sum 
of their decisions, i.e. the performance of the portfolio, and take their decisions based on that. By contrast, according to mental accounting, investors assess their decisions individually and keep track of every single stock purchase on a separate mental account.

One of the consequences of the theory of mental accounting on financial markets is that investors tend to sell stocks earning a return sooner than those generating a loss. When examining the decisions of investors on US stock exchanges, Odean (1998) has also empirically confirmed this consequence of the theory of mental accounting.

\section{Limited self-control}

It is a general observation that people tend to be "present biased". According to the assumption of Strotz (1955) it is an innate nature of humans to disproportionately overrate current consumption over future consumption. Based on the famous example of Thaler (1981), people would rather have one apple today than two apples tomorrow. As opposed to this, people would rather want two apples in one year and one day, than one apple in one year. In both cases, they offer a 100 per cent return in exchange for waiting one day. But still, people are impatient when they could obtain something in the present, and they are patient when in both cases they can obtain the apple only in the future. So this contradicts the generally accepted economic approach which uses exponential discounting to express the time value. The new discounting theorem, which also takes into account the present bias, is referred to as hyperbolic discounting.

We should also differentiate between the two discounting theories in terms of their role within modelling. Exponential discounting did not become widely used in economic modelling because it describes human behaviour well, but because it is the only discounting theory which is consistent (Samuelson 1937). So exponential discounting, as a normative model, wants to capture how people should think to avoid self-contradiction. As opposed to this, hyperbolic discounting (for example Laibson 1997) wants to describe the behaviour of people accurately and thereby provide a more precise forecast of the evolution of economic developments.

Formally, exponential discounting gives the present value of the usefulness of consumption according to the following principle:

$$
\sum_{t=0}^{\infty} \delta^{t} u\left(c_{t}\right),
$$

where $\delta$ denotes the discount factor, $t$ denotes the time period and $u\left(c_{t}\right)$ denotes the usefulness of consumption in period $t$.

By contrast, hyperbolic discounting (Laibson 1997) provides the present value in the following form: 


$$
u\left(c_{0}\right)+\sum_{t=1}^{\infty} \beta \delta^{t} u\left(c_{t}\right)
$$

This formula only differs from exponential discounting in that it multiplies future consumption by a $0<\beta<1$ parameter, which means it undervalues future consumption beyond the time value over the present consumption.

One of the most important phenomena captured by hyperbolic discounting is the time-inconsistent behaviour. Hyperbolic discounting is able to model fairly well when someone decides what they would do in the future, but when they arrive at that point in time, they change their plan: for example, when someone wants to quit smoking, but keeps postponing the first step. Another famous example is when people decide to exercise more in the future, but in the end they fail to do so (Vigna - Malmendier 2006), also shows well why people save too little (Laibson 1997). In Hungary, for example, the popularity of foreign currency loans had a number of underlying demand, supply and institutional factors (Kolozsi et al. 2015), but the lack of self-control might also have contributed to its popularity, which must be handled on the regulatory level as well (Fömötör et al. 2017).

Experiments prove that animals also behave similarly (Ainslie 1974), and tend to have a present bias in their decisions. Thaler (1981) was the first one to demonstrate this in relation to humans as well. In addition, he also found that humans tend to discount their gains more than their losses. Moreover, we tend to discount smaller amounts more than larger amounts. Similar anomalies can also be observed in Hungary in discounting (Neszveda-Dezső 2012).

Thaler and Shefrin jointly developed the planner-doer model to explain our present bias (Thaler - Shefrin 1981; Shefrin - Thaler 1988). Based on the theory already used in psychology, they assume that people have two contradicting selves competing with each other. One is the planner self, while the other is the doer self. The planner maximises lifetime utility, while the doer self only wants to maximise current consumption. The planner self also knows this, so it maximises the utility account taken of this.

An alternative approach to the planner-doer model is when they assume hyperbolic discounting on behalf of people, but they also assume that people also know about themselves that they are present biased. The consequence of these models is the empirically observable fact that people tend to intentionally limit their future selves because they know that by the time they get there, they won't be able to take the right decision. For example, one tool helping this commitment is Antabuse, which causes nausea when alcohol is consumed. The saying "do not shop when you are hungry" captures this very phenomenon (Royal Swedish Academy of Sciences 2017). 


\section{Social preference}

Numerous economic models assume that decision-makers act out of self-interest. This greatly simplifies the mathematical resolution of the models, and also proves to be a good approximation in the majority of the cases. But it can often be clearly demonstrated that people simply do not follow their self-interest but also consider fairness an important criterion. Before Thaler, Adam Smith (1759), and later on Gary Becker (1974) and Amartya Sen (1977) had mentioned the role of fairness too.

Similarly to their predecessors, the work of Thaler, Kahneman and Knetsch (1986) also strongly emphasises the role and significance of fairness in economic thinking. Their experiments extended to three key areas where they exerted strong influence. According to their findings, (1) people are often willing to act based on the principle of fairness even when they take their decisions anonymously and do not have to worry about the loss of their reputation or other losses; (2) they are willing to sacrifice their own resources to punish those who treated them unfairly; (3) they are even willing to give up their own resources to punish those who treated others unfairly.

One of the most important experimental mechanisms for examining fairness, i.e. the Dictator Game, is also partly related to Thaler (Kahneman et al. 1986). In the Dictator Game, participants are paired randomly and everyone remains anonymous throughout and after the experiment. One of the two individuals is given a quantity of money and is told that he must offer some of that money to the second participant. This offering takes place in the experiment in such a way that the other participant cannot be influenced in any way. According to the assumption of complete self-interest, everyone should keep the entire amount to himself. By contrast, the majority of the participants do not keep the whole sum, which shows that people are not entirely driven by self-interest, and fairness is also important to them. Based on 129 articles, taking into consideration the results of 616 experiments, Engel (2011) prepared a summary where he found that people offered on average 28 per cent of the available amount to the other person. Moreover, only 36 per cent of the participants kept the whole sum, while 17 per cent of the participants halved the money between the two of them. Over the years the Dictator Game became an accepted tool for measuring fairness (Konow 2000).

Another famous experiment next to the Dictator Game is the Ultimatum Game (Kahneman et al. 1986). In this game, participants are also paired randomly, and everyone remains anonymous throughout and after the experiment. In this case as well, similarly to the previous game, one member of the couple receives a sum of money and can decide on how to distribute it between them. But here, the other member of the couple can also decide whether to accept the offered sum or not. If they accept it, then the final payment takes place according to the offered 
allocation. If they do not accept it, then both of them leave empty-handed and receive nothing. According to the economic theory built on self-interest, the other member of the couple should accept every sum offered which is more than zero. By contrast, people tend to only accept the offer if it is of a considerably higher value, even though they know that they will end up worse. This shows that people are even willing to give up financial gain to punish those who give an unfair offer (Fehr - Gächter 2000). Hungarian economists (Ambrus-Lakatos - Meszerics 2003) have come to the same results, in line with the international findings.

One of the most important methods for the mathematical modelling of social preferences is the Fehr-Schmidt model (Fehr-Schmidt 1999), where $N$ number of participants are involved and $x_{i}$ denotes the sum of money that participant number $i$ receives. The utility of participant $i$ :

$$
U_{i}\left(x_{i}, x_{j}\right)=x_{i}-\frac{\alpha_{i}}{N-1} \sum_{j=1}^{N} \max \left(x_{j}-x_{i}, 0\right)-\frac{\beta_{i}}{N-1} \sum_{j=1}^{N} \max \left(x_{i}-x_{j}, 0\right),
$$

where $\alpha$ denotes how frustrated he is if the others receive more than him, while $\beta$ designates how frustrated he is if he receives more than the others. So this means that people are frustrated if they receive more than the others (see the Dictator Game) but they are also frustrated if they receive less (see the Ultimatum Game).

\section{Financial markets and behavioural finance}

Behavioural economics and experiments and surveys similar to the ones presented above reveal a number of interesting correlations, but the (same) question always arises in relation to these results: what is their impact in real life, and to what extent can we take such an analysis seriously under real circumstances. The explanation of financial markets is one of the most exciting fields of behavioural economics. According to Fama (1970), financial markets remain efficient even though there are many irrational investors, because rational investors will always correct the effect of irrational investors.

By contrast, Thaler describes in many of his papers that this is not necessarily true. In his approach, investors do not necessarily behave according to the mainstream economic models and rational investors are unable to fully correct the effects so created due to the possibility of limited arbitrage. For example, according to the general assumption, the expectations of investors are accurate, which are always updated according to the Bayes rule whenever new information emerges on the market. But the results of Tversky and Kahneman (1974) suggest that this is often not true, and people tend to overestimate the relevance of a piece of news. Bondt and Thaler (1985) tested this very aspect on the financial markets. They found that shares sustaining a large loss realised a higher return later on compared to the shares which previously had appreciated strongly in value. This suggests that the 
losing stocks (those sustaining a large loss in value) became undervalued because investors overreacted to the relevance of the information, while profitable stocks became overvalued because, again, the investors overreacted to the positive news. The same effect was also observed at the Budapest Stock Exchange (Lakatos 2016).

Benartzi and Thaler (1995) also give an explanation for the equity premium puzzle (Mehra-Prescott 1985) with their behavioural economics-based approach. The puzzle of the equity premium is that under the usual economic assumptions, equity market returns are disproportionately higher than the risk-free return. Benartzi and Thaler examined whether loss aversion and investor horizon can explain this high equity market return. Applying the usual loss-aversion coefficient, their model properly predicted the average higher equity market returns during a one-year evaluation period. So, their explanation for high returns on the equity market is that investors evaluate their decisions each year and assess their current losses, if any, as disproportionately painful. But this is considerably more frequent in the case of stocks compared to a risk-free return; therefore, they are only willing to invest in stocks assuming a very high expected return. During later research, Barberis and Huang (2001) also incorporated mental accounting into their model, thanks to which they are able to explain even more phenomena on the financial markets.

It is also thanks to the work of Thaler that a new field emerged from the crossing of behavioural economics and finance, referred to as behavioural finance. But of course, behavioural finance is not the only and not the generally accepted explanation for the phenomena described above, though it remains one of the most frequently used and researched areas within finance to date.

\section{The impact of Thaler's work on regulations}

From the perspective of regulations, it is important to know what the results of behavioural economics mean regarding human rationality. According to one of the approaches, people are irrational and are often unable to decide what is best for them. According to the other approach, the assumptions of the rational models are not yet appropriate, and people cannot be told what they know correctly or incorrectly. In agreement with many other psychologists, Thaler thinks that people often simply do not possess sufficient cognitive capacities or sufficient willpower. He clearly argues that people often do not know what is best for them.

But this raises a number of sensitive questions. Who decides what is good or wrong for others? What happens if someone knows what they want, but are still forced into a "generally good" decision based on some theory? In light of the benefits and the challenges, Thaler and his partners developed libertarian paternalism (Thaler-Sunstein 2003). According to this theory, useful changes can be achieved through minimal intervention. Based on the theory of libertarian paternalism, the 
intervention (affecting behaviour) "tries to influence choices in a way that will make choosers better off, as judged by themselves" while limiting no one in their choice (freedom of choice).

One of the most typical examples for setting the decision-making structure is the default effect. The default decision, according to the default effect, is triggered if a given person does not dispose otherwise. So if someone wants another decision, they have to declare it separately. One of the best-known cases of the default effect is related to organ donation (Johnson - Goldstein 2003). In countries where the default case is that citizens donate their organs, the rate of usable organs is considerably higher than in those countries where it is not the default case that they donate their organs, and they have to give a separate declaration to that effect. The default effect results in a similarly strong difference for decisions related to pension savings (Madrian - Shea 2001). In line with international experience, 97 per cent of people in Hungary re-entered the state pension system (Baksay - Palotai 2017), which might have been attributable, among many other reasons, to the fact that this was also the default decision.

The findings of Thaler in the field of limited self-control had a tremendous influence on topics dealing with various financial decisions and financial awareness. They formulated their own program based on their research results, which can help people take better financial, and as part of this, better savings-related decisions. Their program "Save More Tomorrow", or SMarT, is composed of four main points.

The first and most important point: they ask people whether they would increase their savings when they receive their next salary raise. In response, people no longer decide between their current consumption and future consumption, but between two future consumptions. Based on hyperbolic discounting and present bias, this results in a considerably more patient decision, leading to a greater willingness to save.

The second point: because the rate of savings will only increase after a future salary raise, people do not deem this as a loss. This is important because according to behavioural economics, people are way too sensitive to losses.

The third point: the rate of savings keeps increasing after every salary raise. So according to the plan, the increases take place automatically. This makes continuous growth the default scenario, from which people always deviate less. And finally, the rate of savings can never increase beyond a predefined value, so the increase remains under control over the years.

The fourth point: participants can leave the program at any time, they take part in it on a voluntary basis as long as it is convenient for them. This guarantees that no one feels they are committing themselves to something they will regret later on. 
In addition, it is also important that no-one is forced to do anything, not even the individuals who have different preferences or would take a rational decision anyway.

They tested the efficacy of the program at several companies, and based on the results, introducing the program increased retirement savings in the USA by an order of magnitude (Benartzi - Thaler 2013), and similar results were obtained in Denmark (Chetty et al. 2014).

Libertarian paternalism proved a popular theorem among the decision-makers of many countries. They started to use the theorem of libertarian paternalism mainly in the United States and the United Kingdom, primarily in the areas of retirement savings, healthcare and education. But there has also been much criticism of the theory for trying to intentionally influence consumers, thus threatening their freedom of choice (Infante et al. 2016; Sugden 2013). But the question may also arise as to which parameters the regulator should use to maximise the common welfare function over "individual errors", and whether it is possible at all to formulate such a welfare function. Moreover, many may resent being manipulated even though they agree with the objectives.

But next to criticism, many research results were also published underpinning the support for libertarian paternalism. Governments and regulators often try to shape processes using expensive instruments, but by contrast, the simple interventions used based on the results of behavioural economics may be considerably cheaper and more efficient. From that perspective, the interventions made based on the theory of libertarian paternalism can be accepted much more (Benartzi et al. 2017). In line with the critical observations, Thaler et al. have also found that not every change may be desirable, therefore the expected effects of the interventions must always be properly and thoroughly tested.

\section{Conclusion}

Richard Thaler's achievements and his contribution to economic research has enjoyed unwavering success over more than 40 years, with an h-index currently standing at 93. This means that he has 93 publications whose citation rate is 93. His most cited paper is the one presenting and laying down the foundation for libertarian paternalism (Thaler - Sunstein 2008), which was referenced more than nine thousand times. His second most cited publication presents the overreaction of stock exchange prices (Bondt - Thaler 1985), with nearly eight thousand references. His third most frequently cited paper, the study laying down the foundation for the theory of mental accounting (Thaler 1985) was referenced nearly six thousand times. These achievements also show that Thaler has not only achieved exciting and interesting scientific results with his work, he has really opened up new research areas within the field of behavioural economics. Moreover, with his scientific work, 
Richard Thaler has incorporated the results of behavioural economics into the public sphere. With his theory of libertarian paternalism, he has greatly influenced the leaders and decision-makers of many countries. His research results have been used in practice to resolve numerous important social issues.

\section{References}

Ainslie, G. W. (1974): Impulse Control in Pigeons. Journal of the Experimental Analysis of Behavior, 21(3): 485-489. https://doi.org/10.1901/jeab.1974.21-485

Ambrus-Lakatos, L. - Meszerics, T. (2003): Az ultimátumjáték elemzéséhez (For the analysis of the Ultimatum Game). Közgazdasági Szemle, 50(6): 505-518.

Baksay, G. - Palotai, D. (2017): Válságkezelés és gazdasági reformok Magyarországon (Crisis management and economic reforms in Hungary), 2010-2016. Közgazdasági Szemle, 44(4): 698-722.

Barberis, N. - Huang, M. (2001): Mental Accounting, Loss Aversion and Individual Stock Returns. The Journal of Finance, 56(4): 1247-1292. https://doi.org/10.1111/00221082.00367

Becker, G. S. (1974): A Theory of Social Interactions. Journal of Political Economy, 82(6): 1063-1093. https://doi.org/10.1086/260265

Benartzi, S. - Thaler, R. H. (1995): Myopic Loss Aversion and the Equity Premium Puzzle. The Quarterly Journal of Economics, 110(1): 73-92. https://doi.org/10.2307/2118511

Benartzi, S. - Thaler, R. H. (2013): Behavioural Economics and the Retirement Savings Crisis. Science, 339(6124): 1152-1153. https://doi.org/10.1126/science.1231320

Benartzi, S. - Beshears, J. - Milkman, K. L. - Sunstein, C. R. - Thaler, R. H. - Shankar, M. W. Tucker-Ray - W. J. Congdon - Galing, S. (2017): Should Governments Invest More in Nudging? Psychological Science, 28(8): 1041-1055.

https://doi.org/10.1177/0956797617702501

Bondt, W. F. - Thaler, R. (1985): Does the stock market overreact? The Journal of Finance, 40(3): 793-805. https://doi.org/10.1111/j.1540-6261.1985.tb05004.x

Camerer, C. - Babcock, L. - Loewenstein, G. - Thaler, R. (1997): Labor Supply of New York City Cabdrivers: One Day at a Time. The Quarterly Journal of Economics, 112(2): 407-441. https://doi.org/10.1162/003355397555244

Chetty, R. - Friedman, J. N. - Leth-Petersen, S. - Nielsen, T. H. - Olsen, T. (2014): Active vs. Passive Decisions and Crowd-out in Retirement Savings Accounts: Evidence from Denmark. The Quarterly Journal of Economics, 129(3): 1141-1219. https://doi.org/10.1093/qje/ qju013 
Engel, C. (2011): Dictator Games: A Meta Study. Experimental Economics, 14(4): 583-610. https://doi.org/10.1007/s10683-011-9283-7

Fama, E. F. (1970): Efficient Capital Markets: A Review of Theory and Empirical Work. The Journal of Finance, 25(2): 383-417. https://doi.org/10.2307/2325486

Fehr, E. - Gächter, S. (2000): Fairness and Retaliation: The Economics of Reciprocity. Journal of Economic Perspectives, 14(3): 159-181. https://doi.org/10.1257/jep.14.3.159

Fehr, E. - Schmidt, K. M. (1999): A theory of fairness, competition, and cooperation. Quarterly Journal of Economics, 114(3): 817-868. https://doi.org/10.1162/003355399556151

Fömötör, B. - Parádi-Dolgos, A. - Sipiczki, Z. (2017): Behavioural Finance and Consumer Loan Contracts. Financial and Economic Review, 16(2): 156-169. http://doi.org/10.25201/ FER.16.2.156169

Golovics, J. (2015): Bounded rationality and altruism: behaviourism in economics. Financial and Economic Review, 14(2): 158-172. http://english.hitelintezetiszemle.hu/letoltes/6golovics-en.pdf

Infante, G. - Lecouteux, G. - Sugden, R. (2016): Preference Purification and the Inner Rational Agent: a Critique of the Conventional Wisdom of Behavioural Welfare Economics. Journal of Economic Methodology, 23(1): 1-25. https://doi.org/10.1080/1350178X.2015.1070527

Johnson, E. J. - Goldstein, D. (2003): Do Defaults Save Lives? Science, 302(5649): 1338-1339. https://doi.org/10.1126/science.1091721

Kahneman, D. - Knetsch, J. L. - Thaler, R. H. (1986): Fairness and the Assumptions of Economics. Journal of Business, 59(4): 285-300. https://doi.org/10.1086/296367

Kahneman, D. - Knetsch, J. L. - Thaler, R. H. (1990): Experimental Tests of the Endowment Effect and the Coase Theorem. Journal of Political Economy, 98(6): 1325-1348. https://doi.org/10.1086/261737

Kolozsi, P.P. - Banai, Á. - Vonnák, B. (2015): Phasing out household foreign currency loans: schedule and framework. Financial and Economic Review, 14(3): 60-87. http://english. hitelintezetiszemle.hu/letoltes/3-kolozsi-banai-vonnak-en.pdf

Konow, J. (2000): Fair Shares: Accountability and Cognitive Dissonance in Allocation Decisions, American Economic Review, 90(4): 1072-1091. https://doi.org/10.1257/ aer.90.4.1072

Laibson, D. (1997): Golden Eggs and Hyperbolic Discounting. The Quarterly Journal of Economics, 112(2): 443-478. https://doi.org/10.1162/003355397555253 
Lakatos, M. (2016): A befektetői túlreagálás empirikus vizsgálata a Budapesti Értéktőzsdén (Empirical study of investor overreaction on the Budapest Stock Exchange. Közgazdasági Szemle, 43(4): 762-786.

Madrian, B. C. - Shea, D. F. (2001): The Power of Suggestion: Inertia in 401 (k) Participation and Savings Behavior. The Quarterly Journal of Economics, 116(4): 1149-1187. https://doi.org/10.1162/003355301753265543

Mehra, R. - Prescott, E. C. (1985): The Equity Premium: A Puzzle. Journal of Monetary Economics, 15(2): 145-161. https://doi.org/10.1016/0304-3932(85)90061-3

Neszveda, G. - Dezső, L. (2012): A kvázi- és általánositott hiperbolikus diszkontálás hosszú távon (Quasi-and generalised hyperbolic discounting in the long run). Szigma, 43(3-4): 163-177.

Odean, T. (1998): Are Investors Reluctant to Realize their Losses? The Journal of Finance, 53(5): 1775-1798. https://doi.org/10.1111/0022-1082.00072

Royal Swedish Academy of Sciences (2016): Scientific Background on the Sveriges Riksbank Prize in Economic Sciences in Memory of Alfred Nobel 2017 - Richard H. Thaler: Integrating Economics with Psychology. 1-37.

Samuelson, P. A. (1937): A Note on Measurement of Utility. The Review of Economic Studies, 4(2): 155-161. https://doi.org/10.2307/2967612

Sen, A. K. (1977): Rational Fools: A Critique of the Behavioral Foundations of Economic Theory. Philosophy \& Public Affairs, 6(4): 317-344.

Shefrin, H. M. - Thaler, R. H. (1988): The Behavioral Life-cycle Hypothesis. Economic inquiry, 26(4): 609-643. https://doi.org/10.1111/j.1465-7295.1988.tb01520.x

Smith, A. (1759): Theory of Moral Sentiments. Millar Press. https://doi.org/10.1093/oseo/ instance.00042831

Strotz, R. H. (1955): Myopia and Inconsistency in Dynamic Utility Maximization. The Review of Economic Studies, 23(3): 165-180. https://doi.org/10.2307/2295722

Sugden, R. (2013): The Behavioural Economist and the Social Planner: to Whom Should Behavioural Welfare Economics be Addressed? Inquiry, 56(5): 519-538.

https://doi.org/10.1080/0020174X.2013.806139

Thaler, R. H. (1980): Toward a Positive Theory of Consumer Choice. Journal of Economic Behavior and Organization, 1(1): 39-60. https://doi.org/10.1016/0167-2681(80)90051-7

Thaler, R. H. (1981): Some Empirical Evidence on Dynamic Inconsistency. Economics Letters, 8(3): 201-207. https://doi.org/10.1016/0165-1765(81)90067-7 
Thaler, R. H. (1985): Mental Accounting and Consumer Choice. Marketing Science, 4(3): 199-214. https://doi.org/10.1287/mksc.4.3.199

Thaler, R. H. - Shefrin, H. M. (1981): An Economic Theory of Self-control. Journal of Political Economy, 89(2): 392-406. https://doi.org/10.1086/260971

Thaler, R. H. - Sunstein, C. R. (2003): Libertarian Paternalism. American Economic Review, 93(2): 175-179. https://doi.org/10.1257/000282803321947001

Thaler, R. H. - Sunstein, C. R. (2008): Nudge: Improving decisions about health, wealth, and happiness. Constitutional Political Economy, 19(4): 356-360. https://doi.org/10.1007/ s10602-008-9056-2

Tuncel, T. - Hammitt, J. K. (2014): A New Meta - Analysis on the WTP/WTA Disparity. Journal of Environmental Economics and Management, 68(1): 175-187. https://doi.org/10.1016/ j.jeem.2014.06.001

Tversky, A. - Kahneman, D. (1974): Judgment under Uncertainty: Heuristics and Biases. Science, 185(4157): 1124-1131. https://doi.org/10.1126/science.185.4157.1124

Tversky, A. - Kahneman, D. (1981): The Framing of Decisions and the Psychology of Choice. Science, 211(4481): 453-458. https://doi.org/10.1126/science.7455683

Tversky, A. - Kahneman, D. (1992): Advances in Prospect Theory: Cumulative Representation of Uncertainty. Journal of Risk and Uncertainty, 5(4): 297-323. https://doi.org/10.1007/ BF00122574

Vigna, S. D. - Malmendier, U. (2006): Paying not to go to the gym. The American Economic Review, 96(3): 694-719. https://doi.org/10.1257/aer.96.3.694 